\title{
Penerapan Generalized Cross Validation dalam Model Regresi Smoothing Spline pada Produksi Ubi Jalar di Jawa Tengah
}

\author{
Trionika Dian Wahyuningsih ${ }^{1}$, Sri Sulistijowati Handajani ${ }^{2}$, and Diari Indriati ${ }^{3}$ \\ ${ }^{1,3}$ Program Studi Matematika FMIPA Universitas Sebelas Maret \\ ${ }^{2}$ Program Studi Statistika FMIPA Universitas Sebelas Maret \\ rr_ssh@staff.uns.ac.id, trionikadian2@gmail.com
}

\begin{abstract}
Sweet Potato is a useful plant as a source carbohydrates, proteins, and is used as an animal feed and ingredient industry. Based on data from the Badan Pusat Statistik (BPS), the production fluctuations of the sweet potato in Central Java from year to year are caused by many factor. The production of sweet potato and the factors that affected it if they are described into a pattern of relationships then they do not have a specific pattern and do not follow a particular distribution, such as harvest area, the allocation of subsidized urea fertilizer, and the allocation of subsidized organic fertilizer. Therefore, the production model of sweet potato could be applied into nonparametric regression model. The approach used for nonparametric regression in this study is smoothing spline regression. The method used in regression smoothing spline is generalized cross validation (GCV). The value of the smoothing parameter $(\lambda)$ is chosen from the minimum GCV value. The results of the study show that the optimum $\lambda$ value for the factors of harvest area, urea fertilizer and organic fertilizer are 5.57905e-14, 2.51426e-06, and 3.227217e13 that they result a minimum GCV i.e 2.29272e-21, 1.38391e-16, and 3.46813e-24.
\end{abstract}

Keywords: Sweet potato, nonparametric, smoothing spline, generalized cross validation.

\section{Pendahuluan}

Indonesia sebagai negara beriklim tropis, memiliki tanah subur dan hasil alam yang beraneka ragam, khususnya di bidang pertanian. Pertanian dalam arti luas terdiri atas lima sektor yaitu tanaman pangan, perkebunan, peternakan, perikanan, dan kehutanan (Soekartawi [1]). Sektor tanaman pangan yang salah satunya adalah tanaman palawija yaitu ubi kayu, ubi jalar, dan talas (Purwono dan Purnamawati [2]). Sebagai salah satu tanaman pangan, ubi jalar merupakan sumber karbohidrat dan protein.

Provinsi Jawa Tengah termasuk ke dalam lima daerah sentra produksi ubi jalar terbesar di Indonesia. Produksi ubi jalar sebagai bahan pangan pengganti merupakan suatu hal yang perlu diperhatikan agar tidak menjadi ancaman untuk ketahanan pangan Jawa Tengah dan Nasional. Produksi ubi jalar Jawa Tengah mengalami fluktuatif dari tahun ke tahun, hal ini disebabkan oleh berbagai faktor, antara lain luas panen, luas lahan, bibit, jumlah pupuk, jumlah tenaga kerja, curah hujan, dan konsumsi masyarakat. 
Najwah [3] melakukan analisis efisiensi usaha tani ubi jalar (Ipomoea batatas L.) di Kabupaten Karanganyar dan menghasilkan kesimpulan bahwa luas lahan, bibit, pupuk phonska, pestisida, dan tenaga kerja berpengaruh nyata terhadap produksi ubi jalar. Selain itu, Defri [4] melakukan analisis pendapatan dan faktor-faktor yang memengaruhi produksi usahatani ubi jalar (studi kasus Desa Purwasari, Kecamatan Dramaga, Kabupaten Bogor). Hasil penelitian tersebut menyatakan estimasi parameter ordinary least square untuk fungsi produksi Cobb-Douglass menunjukkan bahwa variabel yang berpengaruh terhadap produksi ubi jalar adalah variabel pupuk kandang, bibit, dan tenaga kerja.

Penelitian yang dilakukan Najwah [3] dan Defri [4] belum memeroleh hasil yang memuaskan. Hal ini disebabkan produksi ubi jalar dan faktor yang memengaruhinya jika digambarkan ke suatu pola maka tidak memiliki pola tertentu. Oleh karena itu, pola tersebut tidak dapat digunakan dengan regresi parametrik sehingga digunakan regresi nonparametrik. Model regresi nonparametrik digunakan apabila tidak ada informasi sebelumnya tentang bentuk kurva regresi. Salah satu pendekatan regresi nonparametrik untuk memeroleh dugaan kurva regresi adalah smoothing spline. Menurut Aydin [5] smoothing spline memiliki hasil yang lebih baik daripada regresi kernel. Masalah utama pada saat menduga fungsi regresi smoothing spline adalah memilih dan menentukan parameter pemulus (Cantoni dan Hastie [6]).

Menurut Lee [7], untuk menentukan parameter pemulus pada regresi smoothing spline tersebut dapat digunakan metode GCV. Dalam penelitian ini digunakan metode GCV untuk mendapatkan hasil yang maksimum pada parameter pemulus $(\lambda)$. Nilai $\lambda$ dipilih dari nilai $\operatorname{GCV}(\lambda)$ yang minimum.

\section{Model Regresi Nonparametrik}

Menurut Eubank [8] model regresi nonparametrik merupakan model regresi yang digunakan untuk mengestimasi kurva regresi yang hanya tergantung pada data amatan. Model regresi nonparametrik tidak memberikan asumsi terhadap bentuk kurva regresi. Kurva tersebut hanya diasumsikan termuat dalam suatu ruang fungsi tertentu, dimana pemilihan ruang fungsi ini biasanya dimotivasi oleh sifat kemulusan (smoothness) yang diasumsikan dimiliki oleh fungsi regresi tersebut. Ini memberikan fleksibilitas yang lebih besar di dalam bentuk yang mungkin dari kurva regresi. Untuk mengonstruksi model regresinya dipilih ruang fungsi yang sesuai, yang mana kurva regresi diyakini termasuk didalamnya. 
Diberikan $n$ pengamatan $\left(x_{i}, y_{i}\right)$ dengan $i=1,2,3, \ldots, n$ untuk $x_{i}$ dan $y_{i}$ dalam $R$. Variabel $x_{i}$ merupakan variabel prediktor pada pengamatan ke- $i$, variabel $y_{i}$ merupakan variabel respon pada pengamatan ke- $i$, dan $R$ merupakan bilangan riil. Hubungan antara $x_{i}$ dan $y_{i}$ diasumsikan mengikuti model regresi berikut.

$$
y_{i}=f\left(x_{i}\right)+\varepsilon_{i}, i=1,2,3, \ldots, n,
$$

dengan $f\left(x_{i}\right)$ adalah fungsi $f$ yang tidak diketahui dan $\varepsilon_{i}$ adalah sisaan yang diasumsikan berdistribusi normal independen dengan mean nol dan variansi $\sigma^{2}$ (Fox [9]).

Eubank [8] menyatakan bahwa ada beberapa teknik untuk mengestimasi kurva regresi $f$ dalam regresi nonparametrik, salah satunya dengan smoothing spline.

\section{Model Regresi Nonparametrik Spline}

Salah satu model regresi dengan pendekatan nonparametrik yang dapat digunakan untuk menduga kurva regresi adalah regresi spline. Regresi spline merupakan suatu pendekatan ke arah plot data dengan tetap memperhitungkan kemulusan kurva.

Secara umum fungsi spline orde ke- $m$ ditulis sebagai berikut :

$$
f(x)=\beta_{0}+\sum_{j=1}^{m} \beta_{j} x^{j}+\sum_{j=1}^{k} \theta_{j}\left(x-X_{j}\right)_{+}^{m},
$$

dengan fungsi terpotong sebagai berikut :

$$
\left(x-X_{j}\right)_{+}^{m}=\left\{\begin{array}{ll}
\left(x-X_{j}\right)_{+}^{m} & ; x \geq X_{j} \\
0 & ; x<X_{j}
\end{array},\right.
$$

dengan $\beta_{0}$ merupakan parameter model, $\beta_{j}$ merupakan parameter pada variabel $x^{j}, \theta_{j}$ merupakan parameter pada variabel prediktor pemotongan knot ke-j, $x^{j}$ merupakan variabel prediktor orde ke-j, $X_{j}$ merupakan knot ke-j pada variabel $x^{j}$, nilai $j=1,2, \ldots, m$ , $m$ merupakan orde spline, dan $k$ adalah banyak knot.

Dari bentuk matematis fungsi spline, ditunjukkan bahwa spline merupakan model polinomial yang tersegmen (piecewise polynomial), tetapi spline masih bersifat kontinu pada knot-knotnya.

\section{Model Regresi Nonparametrik Smoothing Spline}

Smoothing merupakan suatu proses yang dapat menghilangkan data kasar dengan mengikuti bentuk pola data. Berdasarkan fungsi regresi nonparametrik, $f$ adalah fungsi pemulus dan $E(\varepsilon)=0$, Fahrmeir dan Tuhtz [10] menduga kurva pemulus $\hat{f}\left(x_{i}\right)$ dapat diperoleh berdasarkan data amatan, yakni pasangan variabel prediktor dan variabel respon. Penduga fungsi pemulus merupakan penduga fungsi yang mampu memetakan 
data dengan baik serta mempunyai variansi error yang kecil. Oleh karena itu, dengan menggunakan data amatan sebanyak $n, f\left(x_{i}\right)$ dapat diperoleh dengan meminimumkan fungsi penalized least square (PLS), yaitu

$$
P L S=\sum_{i=1}^{n}\left(y_{i}-f\left(x_{i}\right)\right)^{2}+\lambda \int\left[f^{\prime \prime}(x)\right]^{2} d x
$$

dengan $n$ adalah banyaknya data amatan, $\lambda$ sebagai parameter pemulus dan $f^{\prime \prime}(x)$ adalah fungsi turunan tingkat dua.

\section{GCV (Generalized Cross Validation)}

Metode GCV digunakan untuk menentukan $\lambda$ dalam regresi smoothing spline. Lee [7] mendefinisikan bentuk umum dari metode GCV sebagai berikut

$$
G C V(\lambda)=\frac{1}{n} \frac{\sum_{i=1}^{n}\left\{y_{i}-f_{\lambda}\left(x_{i}\right)\right\}^{2}}{\left\{1-n^{-1} \operatorname{tr}\left(S_{\lambda}\right)\right\}^{2}},
$$

dengan $f_{\lambda}$ adalah estimator dari smoothing spline dan $\operatorname{tr}\left(S_{\lambda}\right) \leq n$. Nilai $\lambda$ dipilih dari nilai $\operatorname{GCV}(\lambda)$ yang minimum.

Adapun langkah-langkah yang dilakukan untuk menentukan $\lambda$ pada regresi smoothing spline diasumsikan sebagai berikut.

1. Input data $\left(x_{1 i}, x_{2 i}, x_{3 i}, \ldots, x_{n i}, y_{i}\right)$.

2. Menghitung matriks $\boldsymbol{T}$ dan $\boldsymbol{H}$ kemudian matriks $\boldsymbol{L}$.

$$
\boldsymbol{T}=\left[\left(\begin{array}{cc}
\boldsymbol{R}+\lambda \boldsymbol{I}_{n} & \boldsymbol{Q}^{t} \\
\boldsymbol{Q} & 0
\end{array}\right)^{-1}\right]_{(n \times n)},
$$

dimana notasi $[.]_{n \times n}$ menunjukkan submatriks berukuran $n \times n$ yang dibentuk dari bagian kiri atas matriks utama

$$
\begin{aligned}
& {\left[\begin{array}{c:c}
T & T_{1} \\
n \times n & n \times 2 \\
\hdashline T_{2} & T_{3} \\
2 \times n & 2 \times 2
\end{array}\right]} \\
& \text { dengan } \boldsymbol{R}=\left(\begin{array}{ccccc}
0 & \frac{\left|x_{1 i}-x_{2 i}\right|^{3}}{12} & \frac{\left|x_{1 i}-x_{3 i}\right|^{3}}{12} & \cdots & \frac{\left|x_{1 i}-x_{n i}\right|^{3}}{12} \\
\frac{\left|x_{2 i}-x_{1 i}\right|^{3}}{12} & 0 & \frac{\left|x_{2 i}-x_{3 i}\right|^{3}}{12} & \cdots & \frac{\left|x_{2 i}-x_{n i}\right|^{3}}{12} \\
\vdots & \vdots & \vdots & \ddots & \vdots \\
\frac{\left|x_{n i}-x_{1 i}\right|^{3}}{12} & \frac{\left|x_{n i}-x_{2 i}\right|^{3}}{12} & \frac{\left|x_{n i}-x_{3 i}\right|^{3}}{12} & \cdots & 0
\end{array}\right) \text {, } \\
& \text { dan } \boldsymbol{Q}=\left(\begin{array}{ccccc}
1 & 1 & 1 & \cdots & 1 \\
x_{1 i} & x_{2 i} & x_{3 i} & \cdots & x_{n i}
\end{array}\right) \text {. }
\end{aligned}
$$

Selanjutnya menentukan nilai $\lambda$ yang diperoleh dari,

$$
\lambda=\frac{1-q}{q}, 0<q<1,
$$


Matriks $\boldsymbol{H}$ didefinisikan sebagai berikut $\boldsymbol{H}=\left(\begin{array}{ll}\boldsymbol{R} & \boldsymbol{Q}^{t}\end{array}\right)\left(\begin{array}{cc}\boldsymbol{R}+\lambda \boldsymbol{I}_{\boldsymbol{n}} & \boldsymbol{Q}^{t} \\ \boldsymbol{Q} & 0\end{array}\right)^{-1}$ merupakan submatriks berukuran $n \times n$ yang di bentuk dari bagian kiri matriks utama,

$\left[\begin{array}{c:c}H & H_{1} \\ n \times n & n \times 2\end{array}\right]$

dan matriks $\boldsymbol{L}$ didefinisikan sebagai $\boldsymbol{L}=\left(\boldsymbol{T} \boldsymbol{H}^{-\mathbf{1}}\right)^{\boldsymbol{t}} \boldsymbol{R} \boldsymbol{T} \boldsymbol{H}^{-\mathbf{1}}$.

3. Menghitung matriks $\boldsymbol{S}_{\lambda}$ dengan $\boldsymbol{S}_{\boldsymbol{\lambda}}=(\boldsymbol{I}+\boldsymbol{\lambda} \boldsymbol{L})^{\mathbf{- 1}}$.

4. Menghitung $f_{\lambda}$ untuk berbagai nilai $\lambda$ dengan $f_{\lambda}=\boldsymbol{S}_{\lambda} y$.

5. Memilih $f_{\lambda}$ yang meminimumkan $\operatorname{GCV}(\lambda)$ dengan $\operatorname{GCV}(\lambda)=\frac{1}{n} \frac{\sum_{i=1}^{n}\left\{y_{i}-f_{\lambda}\left(x_{i}\right)\right\}^{2}}{\left\{1-n^{-1} t r\left(S_{\lambda}\right)\right\}^{2}}$.

\section{Metode Penelitian}

Data yang digunakan dalam penelitian ini adalah data sekunder yang diperoleh dari BPS Provinsi Jawa Tengah berupa produksi ubi jalar di Provinsi Jawa Tengah pada tahun 2015. Variabel respon yang digunakan dalam penelitian ini adalah produksi ubi jalar di 35 kabupaten/kota Jawa Tengah. Variabel prediktor yang digunakan, yaitu luas panen, alokasi pupuk urea bersubsidi, alokasi pupuk organik bersubsidi di Provinsi Jawa Tengah tahun 2015. Data alokasi pupuk urea bersubsidi dan alokasi pupuk organik bersubsidi diperoleh dari Dinas Pertanian, Tanaman Pangan dan Holtikultura Provinsi Jawa Tengah, sedangkan data luas panen dan produksi ubi jalar diperoleh dari BPS Provinsi Jawa Tengah.

Langkah-langkah yang dilakukan untuk mencapai tujuan penelitian.

1. Membuat diagram pencar hubungan antara produksi ubi jalar terhadap masingmasing variabel prediktor.

2. Menentukan nilai $\lambda$ yang digunakan pada masing-masing variabel prediktor.

3. Menentukan nilai estimator smoothing spline pada masing-masing variabel prediktor.

4. Menentukan $\lambda$ optimum berdasarkan nilai GCV minimum pada masing-masing variabel prediktor.

\section{Hasil dan Pembahasan}

7.1 Diagram Pencar Data. Diagram pencar hubungan antara produksi ubi jalar terhadap luas panen, alokasi pupuk urea bersubsidi, dan alokasi pupuk organik bersubsidi dapat dilihat pada Gambar 1. 


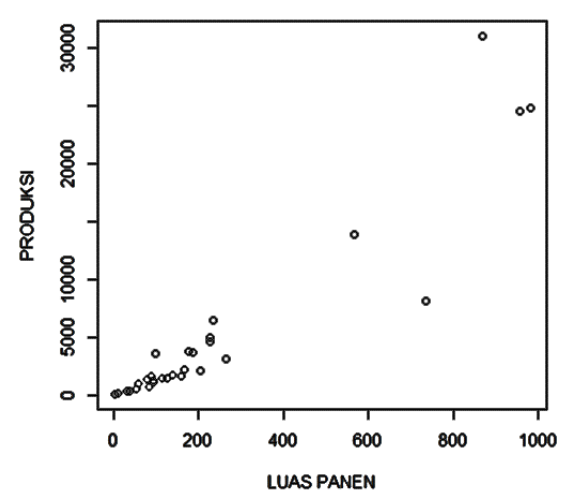

(a)

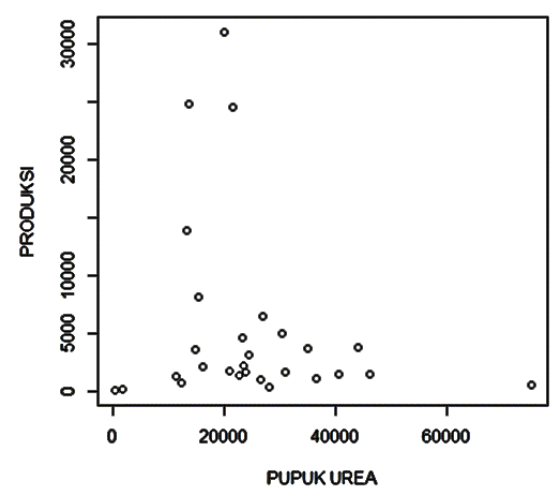

(b)

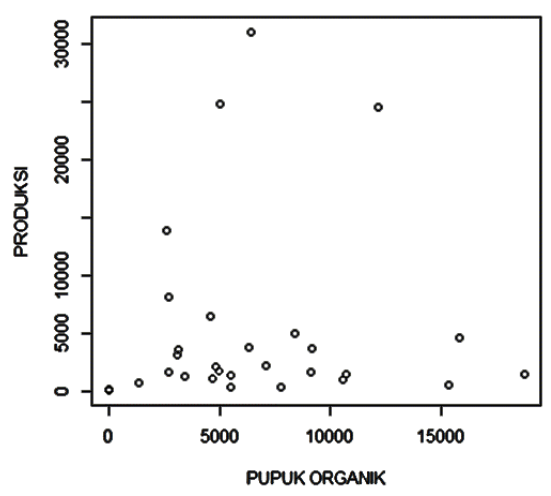

(c)

Gambar 1. Diagram pencar hubungan: (a) produksi ubi jalar terhadap luas panen; (b) produksi ubi jalar terhadap alokasi pupuk urea bersubsidi; (c) produksi ubi jalar terhadap alokasi pupuk organik bersubsidi

Diagram pencar pada Gambar 1 mengindikasikan bahwa data tidak memiliki pola tertentu sehingga tidak mengikuti distribusi tertentu. Produksi ubi jalar dapat diterapkan dalam model regresi nonparametrik. Estimasi fungsi regresi nonparametrik dilakukan berdasarkan data pengamatan dengan menggunakan teknik pemulusan (smoothing). Pendekatan yang digunakan untuk regresi nonparametrik salah satunya adalah pendekatan dengan regresi smoothing spline. Adapun metode yang digunakan dalam regresi smoothing spline adalah metode GCV.

7.2 GCV (Generalized Cross Validation). Metode GCV adalah metode klasik yang digunakan untuk menentukan $\lambda$ pada regresi smoothing spline. Nilai $\lambda$ dipilih dari nilai GCV yang minimum. Langkah yang dilakukan sebelum memeroleh GCV minimum 
adalah menentukan estimator smoothing spline dari berbagai nilai $\lambda$. Matriks estimator smoothing spline berdasarkan nilai $\lambda$ optimum pada masing-masing faktor yang meminimumkan GCV dapat dilihat pada Tabel 4.1.

Tabel 4.1. Nilai $f_{\lambda}$ untuk $\lambda$ optimum pada masing-masing faktor

\begin{tabular}{|c|c|c|c|}
\hline $\begin{array}{l}\text { Variabel } \\
\text { prediktor }\end{array}$ & Luas Panen & Pupuk Urea & Pupuk Organik \\
\hline \multirow{20}{*}{$J$} & 4941.9999999999945 & 4942.000000000024 & 4942. \\
\hline & 1619.9999999999995 & 1619.9999999992783 & 1620.0000000000005 \\
\hline & 3603.999999999982 & 3604.000000000146 & 3604. \\
\hline & 1681.9999999999998 & 1681.9999999996382 & 1682.0000000000002 \\
\hline & 981.9999999999997 & 982.0000000000001 & 982. \\
\hline & 2136. & 2136.000000000001 & 2136. \\
\hline & 8129. & 8128.999999999842 & 8128.999999999998 \\
\hline & 24572.999999999996 & 24573.000000000575 & 24573. \\
\hline & 313.9999999999995 & 314.00000000803686 & 314. \\
\hline & 355.00000000000074 & 354.9999999919489 & 355. \\
\hline & 1598.9999999999975 & 1599.0000000000025 & 1599. \\
\hline & 31076. & 31076.000000000007 & 31076. \\
\hline & 511.0000000000009 & 511.00000000012307 & 511. \\
\hline & 1424.9999999999995 & 1424.9999999998881 & 1425. \\
\hline & 2197.0000000000014 & 2197.000000002583 & 2197. \\
\hline & 1403.0000000000016 & 1402.9999999999889 & 1403. \\
\hline & 1283.999999999979 & 1283.99999999999982 & 1284. \\
\hline & 1315.9999999999964 & 1316.000000000138 & 1316. \\
\hline & 3636. & 3635.99999999999995 & 3636. \\
\hline & 24812. & 24811.999999999807 & 24812. \\
\hline
\end{tabular}




\begin{tabular}{ccc}
\hline 4577.000000000005 & 4576.999999997797 & 4577. \\
6474. & 6474.000000000104 & 6474. \\
13849. & 13849.000000000162 & 13849. \\
738.0000000000056 & 737.9999999999998 & 738. \\
3075. & 3075.0000000000014 & 3075. \\
1075.0000000000377 & 1075.000000000003 & 1075. \\
3742.999999999999 & 3742.9999999998713 & 3743. \\
34.00000000000449 & 34.00000000036755 & 34. \\
150.99999999999517 & 150.99999999967116 & 151.
\end{tabular}

Setelah ditentukan estimator smoothing spline, langkah selanjutnya adalah menentukan nilai GCV yang minimum. Hasil perhitungan dari berbagai nilai $\lambda$ dan nilai GCV ditunjukkan pada Tabel 4.2.

Tabel 4.2. Nilai $\lambda$ dan GCV pada masing-masing faktor

\begin{tabular}{cccccc}
\hline \multicolumn{2}{c}{ Luas Panen } & \multicolumn{2}{c}{ Pupuk Urea } & \multicolumn{2}{c}{ Pupuk Organik } \\
\hline$\lambda$ & GCV & $\lambda$ & GCV & $\lambda$ & GCV \\
\hline $1.362073 .10^{-17}$ & $1.24793 .10^{6}$ & $8.932447 .10^{-21}$ & $8.08271 .10^{7}$ & $7.878948 .10^{-17}$ & 192.012 \\
$5.57905 .10^{-14}$ & $2.29272 .10^{-21}$ & $2.51426 .10^{-6}$ & $1.38391 .10^{-16}$ & $3.227217 .10^{-13}$ & $3.46813 .10^{-24}$ \\
$2.607499 .10^{-5}$ & 0.000493612 & 0.001173893 & $2.60289 .10^{-16}$ & $5.414372 .10^{-6}$ & $2.90679 .10^{-10}$ \\
0.0001376246 & 0.0137452 & 0.01029841 & $2.32165 .10^{-9}$ & 0.0007960934 & $6.28413 .10^{-6}$ \\
0.07624897 & 3248.8 & 42.18229 & 0.0389435 & 0.08525932 & 0.0719865 \\
\hline
\end{tabular}

Berdasarkan Tabel 4.2 nilai GCV minimum dan nilai $\lambda$ optimum untuk masingmasing faktor adalah

1. luas panen: $\lambda=5.57905 .10^{-14} ; \mathrm{GCV}=2.29272 .10^{-21}$

2. pupuk urea: $\lambda=2.51426 .10^{-6} ; \mathrm{GCV}=1.38391 .10^{-16}$

3. pupuk organik: $\lambda=3.227217 .10^{-13} ; \mathrm{GCV}=3.46813 .10^{-24}$.

\section{Kesimpulan}

Berdasarkan hasil dan pembahasan diperoleh kesimpulan bahwa nilai $\lambda$ optimum terhadap faktor luas panen, pupuk urea, dan pupuk organik adalah 5.57905.10 ${ }^{-14}$, 
$2.51426 .10^{-6}$, dan $3.227217 .10^{-13}$ dengan GCV minimum sebesar 2.29272.10 $1.38391 .10^{-16}$, dan $3.46813 .10^{-24}$.

\section{Daftar Pustaka}

[1] Soekartawi, Agribisnis Teori dan Aplikasi, PT. Raja Grafindo Persada, Jakarta, 1999.

[2] Purwono, Purnamawati, H., Budidaya 8 Jenis Tanaman Pangan, Jakarta: Penebar Swadaya, 2007.

[3] Najwah, I. N., Analisis Efisiensi Usahatani Ubi Jalar (Ipomoea batatas L.) di Kabupaten Karanganyar, Skripsi Fakultas Pertanian, Universitas Sebelas Maret, Surakarta, 2014.

[4] Defri, K., Analisis Pendapatan dan Faktor-faktor yang Memengaruhi Produksi Usahatani Ubi Jalar (Studi Kasus Desa Purwasari, Kecamatan Dramaga, Kabupaten Bogor), Skripsi Fakultas Ekonomi dan Manajemen, Institut Pertanian Bogor, Bogor, 2011.

[5] Aydin, D., A Comparison of The Nonparametric Regression Models Using Smoothing Spline and Kernel Regression, World Academy Science, Enginering and Technology, 2007; (36): 253-257.

[6] Cantoni, E. dan Hastie, T., Degrees of Freedom Tests for Smoothing Splines, Statistics Department, Stanford University, 2000.

[7] Lee, T. C. M., Smoothing Parameter Selection for Smoothing Splines: a Simulation Study, Computational Statistic \& Data Analysis, 2003; (42): 139-148.

[8] Eubank, R., Nonparametric Regression and Spline Smoothing. Second Edition, New York: Marcel Dekker, 1999.

[9] Fox, J., Nonparametric Regression [Internet]. 2002 [cited 2009 Jan 24]. Available from: http://cran.r-project.org/doc/contrib/Fox-Companion/appendixnonparametric-regression.pdf, [cited 2017 Jun 02].

[10] Fahrmeir, L. dan Tuhtz, G., Multivariate Statistical Modelling Based on Generalized Linear Models, Springer-Verlag, New York, 1994. 